\title{
Studying Disadvantaged Youths in the Middle East: A Theoretical Framework
}

Manata Hashemi

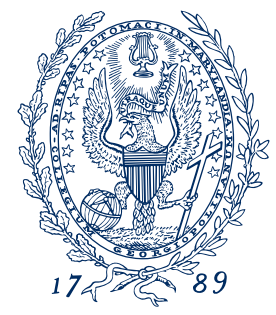

GEORGETOWNC UNIVERSITY

School of Foreign Service in Qatar

Center for International and Regional Studies

(c) 2015 
Studying Disadvantaged Youths in the Middle East: A Theoretical Framework

Manata Hashemi

(C) 2015 Center for International and Regional Studies Georgetown University School of Foreign Service in Qatar

Occasional Paper No. 16 ISSN 2072-5957 


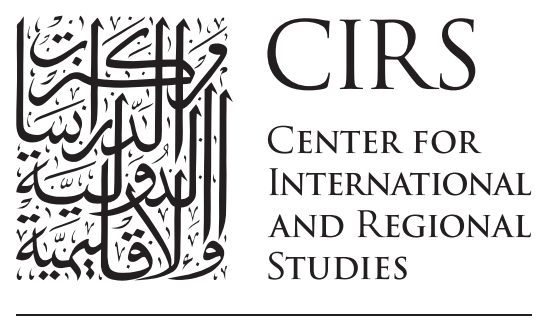

GEORGETOWN UNIVERSITY

SCHOOL OF FOREIGN SERVICE IN QATAR

Established in 2005, the Center for International and Regional Studies at the Georgetown University School of Foreign Service in Qatar is a premier research institute devoted to the academic study of regional and international issues through dialogue and exchange of ideas, research and scholarship, and engagement with national and international scholars, opinion-makers, practitioners, and activists.

Guided by the principles of academic excellence, forward vision, and community engagement, the CIRS mission revolves around five principal goals:

- To provide a forum for scholarship and research on international and regional affairs;

- To encourage in-depth examination and exchange of ideas;

- To foster thoughtful dialogue among students, scholars, and practitioners of international affairs;

- To facilitate the free flow of ideas and knowledge through publishing the products of its research, sponsoring conferences and seminars, and holding workshops designed to explore the complexities of the twenty-first century;

- To engage in outreach activities with a wide range of local, regional, and international partners.

This publication series is made possible by the generous support of Qatar Foundation for Education, Science and Community Development. 


\title{
Studying Disadvantaged Youths in the Middle East: A Theoretical Framework
}

\author{
Manata Hashemi
}

Manata Hashemi is the Farzaneh Family Assistant Professor of Iranian Studies in the Department of International and Area Studies at the University of Oklahoma. A sociologist by training, her research focuses on poverty, social stratification, and mobility in contemporary Iran. She explores generally how cultural norms and moral worldviews inform people's socioeconomic strategies. Hashemi received her BA in Near Eastern Studies from Cornell University, her MA in Regional StudiesMiddle East from Harvard University, and her PhD in Sociology from the University of California-Berkeley. Prior to joining the University of Oklahoma, she was a Research Director at Qatar Foundation and a PostDoctoral Fellow at the Center for International and Regional Studies, Georgetown School of Foreign Service in Qatar. 


\begin{abstract}
Disproportionate levels of youth unemployment and economic marginalization in the Middle East have prompted many regional observers to conclude that socioeconomically disadvantaged Middle Eastern youth are more prone to radicalization and thereby constitute a threat to national and international security. The general consensus in these accounts is that low levels of occupational opportunities leave poor youth more disposed to frustration and fatalism, which in turn are strongly linked to radical politics. Alternatively, scholars in the language of rational choice argue that these young people engage in a deliberate calculation of means and ends in order to attain the power and wealth necessary for upward mobility. These scholars posit poor youth as rational, autonomous agents whose goals are defined by individual interests and preferences. However, these respective theories are unable to account for 1) the absence of political radicalism among poor youth in many countries of the Middle East, and 2) the presence of seemingly irrational acts among these youth that neither maximize self-interest, nor necessarily reflect individual preferences. Given the shortcomings of each of these prevailing theories, this paper, instead, synthesizes these two approaches and assesses the social conduct of poor youth in the Middle East from the perspective of aspirations-bounded rationality. From this vantage point, the behaviors of poor youth are not determined by individual economic interests or by pure emotion, but by aspirations. This paper proposes that these youth struggle and create strategies to improve their lives that are conditioned by experience and observation of those who inform their social worlds.
\end{abstract}




\section{Introduction}

Many regional observers have characterized socioeconomically disadvantaged young men and women in urban areas of Middle Eastern nations as inhabiting a "space of dissidence." ${ }^{1}$ As one study has stated, the threat of "disaffected youth" who have no opportunities to engage in productive employment will lead to the "path of the suicide bomber." ${ }^{2}$ The general consensus in these types of accounts is that depressed economic conditions, as a result of high levels of unemployment and low levels of marketable skills, leave socially and economically marginalized youth (15-29 years) in Middle Eastern societies more disposed to frustration, fatalism, and feelings of powerlessness. ${ }^{3}$ These feelings, in turn, are argued to lead youth to engage in deviant practices to seek the power and dignity that they feel is lacking in their daily lives. These deviant practices are often linked to participation in radical movementsdefined as insurgency and political militancy-thereby causing further regional violence and instability. ${ }^{4}$ Irrationality-defined as extremism in decision-making and social conduct-thus becomes the signifying characteristic of the young and disadvantaged in the Middle East. ${ }^{5}$

\footnotetext{
${ }^{1}$ Salwa Ismail, Political Life in Cairo's New Quarters: Encountering the Everyday State (Minneapolis, MN: University of Minnesota Press, 2006), 127. See also, Hilal Khashan, "Collective Palestinian Frustration and Suicide Bombings," Third World Quarterly 24, no. 6 (2003): 1049-1067; Ali Kouaouci, "Population Transitions, Youth Unemployment, Postponement of Marriage and Violence in Algeria," The Journal of North African Studies 9, no. 2 (2004): 28-45; Mansoor Moaddel and Stuart A. Karabenick, "Religious Fundamentalism among Young Muslims in Egypt and Saudi Arabia," Social Forces 86, no. 4 (2008): 1675-1710; Djavad Salehi-Isfahani, "Growing up in Iran: Tough Times for the Revolution's Children,” Brown Journal of World Affairs 15, no. 1 (2008): 63-74. I thank Cihan Tugal, Martín Sánchez-Jankowski, Suzi Mirgani, and the anonymous reviewers for their insightful comments on previous drafts.

${ }^{2}$ Lionel Barber, "Restive Young a Matter of National Security," Financial Times, June 2, 2008, www. ft.com/reports/youth2008.

${ }^{3}$ Youth, as defined by the Statistical Center of Iran, are those individuals that fall between the ages of $15-29$ years.

${ }^{4}$ It is important to keep in mind that this paper is not arguing that all youth do not take radical extremist paths. Indeed, in the contemporary Middle East, in countries like Iraq and Syria, it is often young recruits who engage in the extremist violence that has become an all too real part of daily life. However, what this paper is arguing is that economic disadvantage is not necessarily a precursor to engagement in extremism, as is often believed to be the case.

${ }^{5}$ See Alejandro Portes, "Rationality in the Slum: An Essay on Interpretive Sociology," Comparative Studies in Society and History 14, no. 3 (June 1972): 268-286.
} 
In response to this imputed irrationality, scholars, in the language of rational choice theory, have alternatively argued that disadvantaged people in the Middle East engage in a deliberate calculation of means and ends in order to attain the power and wealth necessary for upward mobility. ${ }^{6}$ Paying particular attention to the negotiating and bargaining that occurs among family members, these accounts subscribe to the cooperative conflict model of the household. ${ }^{7}$ As such, they argue that the household is not an egalitarian unit, but one that is characterized by "internal conflicts of interest regarding the distribution of the fruits of their [members'] activities." ${ }^{\prime}$ Individual family members act to maximize socioeconomic advantage while simultaneously solidifying their membership in households. Thus, in an attempt to rescue poor Middle Eastern youth from the image of passive subjects, these scholars posit them - and others within the household unit - as rational, autonomous agents whose goals are defined by individual interests and preferences.

This paper is a reaction to both of these homogenizing representations of one of the most populous and significant generations of our time. Heterogeneities that exist among socioeconomically disadvantaged youth in Middle Eastern societies-in particular, heterogeneities in life circumstances, age, gender, sociopolitical contexts, motivations, and beliefs-lead to differences in the ways that these youth cope with unemployment and feelings of powerlessness. These youth can neither be categorized as inhabiting a space of radical dissidence, nor do they always engage in everyday struggles to pursue economic goals that are in line with their individual preferences. Indeed, as Bayat argues, the latter perspective overlooks a holistic understanding of the motives involved in these efforts, where morality is mixed with cost-benefit calculations. ${ }^{9}$

\footnotetext{
${ }^{6}$ Arlene Elowe MacLeod, Accommodating Protest: Working Women, the New Veiling, and Change in Cairo (New York, NY: Columbia University Press, 1991); Diane Singerman, Avenues of Participation: Family, Politics and Networks in the Urban Quarters of Cairo (Princeton, NJ: Princeton University Press, 1995); Homa Hoodfar, Between Marriage and the Market: Intimate Politics and Survival in Cairo (Berkeley, CA: University of California Press, 1997).

7 See Amartya Sen, "Gender and Cooperative Conflicts," in Persistent Inequalities: Women and World Development, ed. Irene Tinker (Oxford: Oxford University Press, 1990), 123-150.

${ }^{8}$ Hoodfar, Between Marriage and the Market, 12.

9 Asef Bayat, Street Politics: Poor People's Movements in Iran (New York, NY: Columbia University Press, 1997).
} 
That is, while actions are structurally determined to the extent that these young people continuously look for the most efficient way of navigating their circumstances, notions of what constitutes maximum efficiency are themselves based on cultural norms. ${ }^{10}$

I argue that socioeconomically disadvantaged youth-those who suffer from conditions of social and economic hardship relative to their peers; those who live below the national poverty lines in their countries; and those who come from working-class families who struggle to make ends meet-make rational choices and engage in rational acts, but within certain cultural bounds. In relying on the language of bounded rationality, I argue that social conduct among these youth is rational in the sense that they do not necessarily act in accordance to extreme emotional states. Youth do act, however, in accordance with cultural values. Attitudes, beliefs, norms, and practices that comprise a young person's cultural world can cause seemingly irrational acts—-such as engaging in fraudulent schemes, preferring unstable work in the informal economy to stable formal sector jobs, or dealing illicit goods on the black market-to seem reasonable. ${ }^{11}$

How can we understand the behaviors of disadvantaged youth in the Middle East? I address this question by critically examining the two dominant analytic approaches used to describe behaviors among marginalized youth, namely affective and rational driven action. I argue that these young people's "orientations to the future" - their aspirations — that are embodied in their particular beliefs, motivations, and norms create coping strategies that are overlooked by current theoretical perspectives. ${ }^{12}$ I build on the work of aspiration-based theorists of individual behavior, namely Arjun Appadurai and Debraj Ray, to argue that these youth do not act to maximize economic security per se, but to pursue their aspirations, which comprise an important

\footnotetext{
${ }^{10}$ See, for instance, David D. Laitin, Hegemony and Cultures: Politics and Religious Change among the Yoruba (Chicago, IL: University of Chicago Press, 1986); and Ann Swidler, Talk of Love: How Culture Matters (Chicago, IL: University of Chicago Press, 2001).

${ }^{11}$ In this paper, the informal economy refers to untaxed and unregulated economic activities. My use of the term informal economy does not refer to illicit economic practices that are directly criminalized such as prostitution and drug trafficking.

${ }^{12}$ Arjun Appadurai, "The Capacity to Aspire: Culture and the Terms of Recognition," in Culture and Public Action, eds. Vijayendra Rao and Michael Walton (Stanford, CA: Stanford University Press, 2004), 60 .
} 
cultural dimension. ${ }^{13}$ This does not mean that poor youth do not bring strategy and calculation into their practices. Rather, I argue that their wants, preferences, and desires are derived from larger cultural valuations and group interactions. In such a way, this paper lays the conceptual groundwork for a theory of human behavior that synthesizes rationality with cultural action.

In arguing for aspirations-bounded rationality, ${ }^{14} \mathrm{I}$ do not suggest that this interpretation is correct in the sense that it exactly captures the motives of all disadvantaged Middle Eastern youth. Indeed, the argument remains largely a theoretical possibility grounded in previous literature and my own preliminary observations of poor youth in Iran. ${ }^{15}$ Rather, I suggest that the utility of the present approach lies in its ability to better explain enduring patterns of behavior among some youth in the Middle East than other theoretical perspectives have done thus far.

\section{Prevailing Perspectives}

\section{Youth Radicalism}

According to Portes, the idea that socially and economically disadvantaged social groups can become radicalized originates from the theory of political extremism. ${ }^{16}$ In this view, a lack of formal education, the absence of meaningful social ties with the broader community, and feelings of social alienation are characteristic of the working classes. ${ }^{17}$ These characteristics, in turn, are argued to result in desires to fit in and to feel secure, which

\footnotetext{
${ }_{13}$ Appadurai, "The Capacity to Aspire;" See also Debraj Ray, "Aspirations, Poverty and Economic Change," Working Paper, New York University and Instituto de Análisis Económico (CSIC), 2003, http://www.econ.nyu.edu/user/debraj/Papers/povasp01.pdf.

${ }^{14}$ The term "bounded rationality" was first used by Herbert Simon to describe the limitations that individuals face in exercising rationality. See Herbert Simon, Models of Man: Social and RationalMathematical Essays on Rational Human Behavior in a Social Setting (Hoboken, NJ: Wiley, 1957).

${ }^{15}$ This research was conducted in the cities of Sari and Tehran in Iran between 2010 and 2012. I conducted participant observation in low-income areas in the two cities among young men and women between the ages of 15-29 who came from families that earned 400,000 tomans/month (approximately $150 \mathrm{USD} / \mathrm{month}$ ) at the time of fieldwork. Most of the youth were high school students, street peddlers, bazaar vendors, and service workers. During fieldwork, I spent time in sites where I knew a large number (anywhere from 5-30) of low-income youth worked or passed through including certain parks, streets, salons, and shops. For more details, see Manata Hashemi, "Waithood and Face: Morality and Mobility among Lower-Class Youth in Iran," Qualitative Sociology 38, no. 3 (2015): 261-283.

${ }^{16}$ See Portes, "Rationality in the Slum."

${ }^{17}$ Seymour Martin Lipset, Political Man: The Social Bases of Politics (Garden City, NY: Anchor Books, 1963).
} 
make radical movements an attractive outlet for finding meaning and power. According to Portes, perspectives such as these tend to characterize radicalism as the logical response to an irrational psychological condition. As Portes emphasizes in a critique of Latin American working-class radicalism, "the possibility of rational action, of a deliberate calculation of means and ends is seldom contemplated. Rather, popular masses are perceived as governed by impulse. Extremism permeates these groups to the extent that they are also permeated by ignorance, social isolation, and irrational aggressiveness." 18

According to Portes, when irrationality is considered to be a signifier of the marginalized, and a contributing factor to nonconformism, then a question arises regarding the identity of the socially excluded and marginalized populations. ${ }^{19}$ For the psychologist, Jean Piaget, irrational behavior is the signifying trait of young age. In Piaget's theory, the development of a child's intelligence is a constructive, developmental process that ends in adult rationality or logic. ${ }^{20}$ Scholars and analysts have utilized this perspective to argue that young people possess certain qualities that cause them to be prone to impulsiveness-especially in "reactive decision making." ${ }^{21}$ In particular, the ascription of irrationality and asocial behavior can often be found in unmitigated statements about marginalized youth in the Middle East.

Indeed, it is frequently the young, poor resident of the Middle East who is considered to embody irrationality and to be the most susceptible to radical behavior. Within this framework, some scholars have utilized a rationalist approach to argue that people who engage in radicalism in the Middle East calculate costs and benefits and act strategically to pursue means and

\footnotetext{
${ }_{18}$ Portes, "Rationality in the Slum," 269.

${ }^{19}$ For more on the link between rationality and poverty, see Saeed Rahnema, "Radical Islamism and Failed Developmentalism," Third World Quarterly 29, no. 3 (2008): 483-496; Alan Richards and John Waterbury, A Political Economy of the Middle East (Boulder, CO: Westview Press, 2008).

${ }^{20}$ See, Bärbel Inhelder, Harold H. Chipman, and Charles Zwingmann, Piaget and His School: A Reader in Developmental Psychology (New York, NY: Sprinter-Verlag, 1976); Allison James and Alan Prout argue that the dominant developmental approach to childhood (based on Piaget's model) is based on the idea that "rationality is the universal mark of adulthood with childhood representing the period of apprenticeship for its development. Childhood is therefore important to study as a presocial period of difference, a biologically determined stage on the path to full human status, i.e. adulthood," in Allison James and Alan Prout, eds. "A New Paradigm for the Sociology of Childhood? Provenance, Promise and Problems," in Constructing and Reconstructing Childhood: Contemporary Issues in the Sociological Study of Childhood, eds. Alan Prout and Allison James (London: The Falmer Press, 1997), 10.

${ }^{21}$ World Bank, World Development Report 2007: Development and the Next Generation (Washington, DC: World Bank, 2006), 16.
} 
ends. ${ }^{22}$ Scholars, such as Hafez, who have studied the causal factors leading to suicide bombings in Palestine, for example, have argued that actors display bounded rationality to the extent that their motivations are shaped by religious faith and structural opportunities, including public support, that validate political violence. Nevertheless, many of the individual actors analyzed come from middle-class or even affluent families. When attention shifts to people from poor backgrounds, it is argued that the disposition to engage in violence "cannot take place without provocation that produces intolerable frustration." ${ }^{23}$ Conditions of poverty are considered to produce a "limited worldview" that breeds "extreme religious ideas." ${ }^{4}$

In a region characterized by authoritarian regimes, such as those found in Egypt and Saudi Arabia, high levels of youth unemployment, limited job opportunities, and limited opportunities for civic and political involvement, regional analysts consider socioeconomically disadvantaged youth as the most restive social group, ${ }^{25}$ and as the demographic most vulnerable to destructive desires such as political violence. ${ }^{26}$ The general consensus is that, given the social and economic restrictions that operate within the region and that are even more salient for disadvantaged youth, these young people may inevitably "turn to the streets and other mischief without a proper outlet for their energies." 27

\section{Youth Irrationality}

The assumption of militancy and extremism among the young and the disadvantaged takes irrationality as its underlying basis. Indeed, the idea of irrational behavior also underlies one of the main approaches that has been used to study marginalized youth in the Middle East: social exclusion.

\footnotetext{
${ }_{22}$ Mohammed M. Hafez, "Rationality, Culture, and Structure in the Making of Suicide Bombers: A Preliminary Theoretical Synthesis and Illustrative Case Study," Studies in Conflict E Terrorism 29, no. 2 (May 2006): 165-185.

${ }^{23}$ Khashan, "Collective Palestinian Frustration and Suicide Bombings," 1064.

${ }^{24}$ Ibid.

${ }^{25}$ Linda Herrera and Asef Bayat, Being Young and Muslim: New Cultural Politics in the Global South and North (Oxford: Oxford University Press, 2010).

${ }^{26}$ Asef Bayat, Making Islam Democratic: Social Movements and the Post-Islamist Turn (Stanford, CA: Stanford University Press, 2007).

${ }^{27}$ Hilary Silver, "Social Exclusion: Comparative Analysis of Europe and Middle East Youth," The Middle East Youth Initiative Working Paper no. 1 (Washington, DC, and Dubai: Wolfensohn Center for Development at Brookings and the Dubai School of Government, September 2007): 9.
} 
The theory of social exclusion, as applied by Silver, Egel, and SalehiIsfahani in relation to youth in the Middle East, ${ }^{28}$ argues that young people are excluded from fully participating in societal relations and institutions, and prevented from fully participating in the normatively prescribed activities of their communities. ${ }^{29}$ Such "accumulation of multiple dimensions of disadvantage" locates this primarily in young people's participation in labor markets. ${ }^{30}$ Within this perspective, it is argued that unemployment prevents youth from participating in the social activities and relations that define youthhood. A lack of employment and inability to gain income makes it difficult for youth to socialize with their counterparts through consumption practices such as wearing certain brand name clothing and dining out, to meeting the rising costs of marriage, and to establishing their own households. The inability to engage in these practices, in turn, constricts their social lives and contributes to their feelings of frustration. As such, these young people are considered to constitute a "potential reserve army from which a variety of political actors [can] draw in their efforts to alter power relations." ${ }^{31}$ Replete with despair and with no constructive outlet for their frustrations, disaffection is assumed to lead to deviant behaviors and ultimately, to uprisings. Thus, it is argued that feelings of frustration and despair propel youth to engage in subversive movements in their respective societies, which can help them to regain their sense of self.

The point of interest in social exclusion theory, then, is the description of the behaviors of socioeconomically disadvantaged youth. Feelings of having

\footnotetext{
${ }^{28}$ Hilary Silver, "Social Exclusion;" Djavad Salehi-Isfahani and Daniel Egel, "Youth Exclusion in Iran: The State of Education, Employment and Family Formation," The Middle East Youth Initiative Working Paper no. 3 (Washington, DC, and Dubai: Wolfensohn Center for Development at Brookings and the Dubai School of Government, September 2007).

${ }^{29}$ For examples of the application of social exclusion theory to youth in the Middle East, see Gema Martín Muñoz, "Arab Youth Today: The Generation Gap, Identity Crisis and Democratic Deficit," in Alienation or Integration of Arab Youth: Between Family, State and Street, ed. Roel Meijer (Richmond, Surrey: Curzon Press, 2000): 17-27; Brahim Boudarbat and Aziz Ajbilou, "Youth Exclusion in Morocco: Context, Consequences, and Policies," The Middle East Youth Initiative Working Paper no. 5 (Washington, DC, and Dubai: Wolfensohn Center for Development at Brookings and the Dubai School of Government, September 2007); Silver, "Social Exclusion;" Salehi-Isfahani, "Growing up in Iran."

${ }^{30}$ Silver, "Social Exclusion," 26.

${ }^{31}$ Kouaouci, "Population Transitions, Youth Unemployment, Postponement of Marriage and Violence in Algeria," 44.
} 
"no hope for the future,"32 and being let down by society as a result of exclusion from the labor market are taken as factors that can lead to frustration and the possibility of violent action. Emotion-based responses, rather than rational action, thus become the defining feature of these youths' behavior. A report conducted on young Tunisians looking for work, for example, concluded that a lack of work resulted in increasing poverty, a loss of confidence, and an increasing tendency to become fatalistic and submissive. ${ }^{33}$

With the foregoing argument, I do not intend to undermine the possibility that social and economic disadvantage can lead youth in the Middle East to engage in deviant behaviors such as drug abuse, participation in youth gangs, or crime. Certainly, such behaviors, though irrational to the extent that they do not constitute the most efficient means for sustaining long-term benefits, are nevertheless common and function to make life manageable and meaningful for the actors involved. ${ }^{34} \mathrm{My}$ point, however, is that within the context of the Middle East, a key assumption underlying narratives of marginalized youth is a "cultural affinity" between young people's existential conditions and militancy. To be sure, while late adolescence and young adulthood is "considered the period of highest susceptibility to the social and political forces people encounter," it has largely been within the context of the Middle East where this susceptibility is believed to be the most prevalent. ${ }^{35}$ However, if one assumes that low-income youth in the Middle East act in ways that are fundamentally emotion-based with little to no rational consideration of the end, the means, and the secondary consequences of their actions, then existing scholarly evidence of the relative absence of radicalism among the majority of youth from low-income backgrounds in the region becomes an intriguing anomaly. ${ }^{36}$

\footnotetext{
${ }^{32}$ Comment made by 17-year-old street vendor in Iran taken from author's own fieldwork.

${ }^{33}$ Mongi Bédoui and Gouia Ridha, "Les Politiques de Lutte Contre L'Exclusion Sociale en Tunisie" (Policies for Fighting Social Exclusion in Tunisia), Working Paper no. 88 (International Institute of Labor Studies, International Labor Office, 1996).

${ }^{34}$ Martín Sánchez-Jankowski, Cracks in the Pavement: Social Change and Resilience in Poor Neighborhoods (Berkeley, CA: University of California Press, 2008).

${ }_{35}$ Moaddel and Karabenick, "Religious Fundamentalism among Young Muslims in Egypt and Saudi Arabia," 1675.

${ }^{36}$ Asef Bayat and Eric Dennis, "Who is Afraid of Ashwaiyyat? Urban Change and Politics in Egypt," Environment \& Urbanization 12, no. 2 (2000): 185-199; Alan B. Krueger, What Makes a Terrorist? Economics and the Roots of Terrorism (Princeton, NJ: Princeton University Press, 2007); John L. Esposito and Dalia Mogahed, Who Speaks for Islam? What a Billion Muslims Really Think (New York, NY: Gallup Press, 2007).
} 


\section{Youth Rationality}

As a way to understand the relative absence of acts of collective radicalism and violence among disadvantaged youth, the work of scholars operating within James Scott's everyday forms of resistance model may provide an explanation. These scholars, including Diane Singerman and Arlene Macleod, have reinterpreted young people's practices within the spheres of their household and community as a means towards enhancing their individual power and/or wealth. ${ }^{37}$ Neither necessarily visible as political militancy nor as fatalistic approaches to socioeconomic marginalization, informal political and economic activities-so the argument goesencroach onto the prevailing political order and influence the distribution of public goods and services. In this view, a marginalized Middle Eastern youth no longer has propensities toward radicalism nor is he/she a passive and hopeless subject of broad market and political reforms. Rather, a youth is an agent who possesses autonomous capacity for social, economic, and political empowerment.

In the language of rational choice, theories of informal politics and accommodating protest have argued that the merging of consent with passive acts of resistance is the logical response embraced by those who understand the costs of acting openly in pursuit of their interests. ${ }^{38}$ Given harsh social controls, ordinary young men and women resort to both formal and informal institutions and actions in order to advance their power, to accrue incremental social and economic gains, and, ultimately, to pursue their own interests. To this end, actions such as working in the informal economy or dressing in a certain fashion constitute ordinary practices of daily life that enable these youth to establish what Bayat terms as a politics of presence. ${ }^{39}$

In Singerman's theory of informal politics, popular classes in Egypt manipulate formal and informal means in order to accomplish economic objectives. These means, which include informal networks, savings associations, black markets, and street vending, are intended to "provide

\footnotetext{
${ }^{37}$ James C. Scott, Weapons of the Weak: Everyday Forms of Peasant Resistance (New Haven, CT: Yale University Press, 1985).

${ }^{38}$ MacLeod, Accommodating Protest.

${ }^{39}$ Bayat, Making Islam Democratic.
} 
for their families, protect their security, and further the collective interests of the community." ${ }^{\prime 0}$ In the absence of state support, the economic power that marginalized citizens gain by participating in these activities provides a way for them to promote their preferences within their families and larger communities. Indeed, according to Singerman, the growth of the informal economy in countries such as Egypt has led to greater social and economic mobility among the working class. Informality thus becomes a sphere of manipulability by marginalized groups in order to develop and enhance their economic and political control.

In a similar vein, MacLeod's theory of accommodating protest interprets young, working-class Egyptian women's participation in the workforce as a consequence of their need for income and their drive toward economic goals. To resolve the incompatibility between traditional gender roles that dictate women's place within the home, and women's economic role that necessitate work in the public sphere, low-income, working Egyptian women don the hijab in order to compensate for this dilemma and to demonstrate to others that they are still conforming to social norms regarding women and motherhood. Veiling among these women thus becomes a symbol of their struggle to claim their right to leave the household—at least for certain periods during the day - to work and to retain mobility in the city. Veiling, within this context, also becomes a low-cost tactic in accommodating prevailing norms in Egypt. In this way, the power of men remains intact and yet is continuously "resisted, limited, altered, [and] challenged." 41

Thus, the adoption of certain modes of dress or participation in informal or extralegal activities constitute a way for disadvantaged youth to pursue wealth and power, even though these acts can also simultaneously operate to entrench them further in systems of inequality. Nevertheless, by picking and choosing among actions that they find convenient for their own situations, disadvantaged youth engage in strategic manipulations to enhance their status within their households and communities.

\footnotetext{
${ }^{40}$ Singerman, Avenues of Participation, 174.

${ }^{41}$ Raymond Williams, Marxism and Literature (Oxford: Oxford University Press, 1977), 112.
} 
Such studies on informal economies and survival strategies draw from the premise that most people, particularly within the developing world and the Middle East, interact with the broader society as members of a household. Factors that affect a person's position within the domestic unit evolve in response to not only social changes, but also to the active struggles or bargaining that occur in intra-household relations. ${ }^{42}$ Nonetheless, even though this household bargaining perspective has been able to demonstrate how variables such as gender and age affect a person's position and life chances, it is still based on an understanding that the goals household members pursue are determined by economic interests and preferences, as evidenced by their engagement in conflicts "regarding the distribution of the fruits of their activities." 43

I argue that this emphasis on purely rational action to capitalize on economic security overlooks the complexity of motives involved in personal decisions. If we assume that marginalized youth will act solely to maximize their material interests, then how can we explain, for instance, why some unemployed young people in Iran refuse job offers, or why they resist leaving towns that offer limited mobility opportunities? Rational-utilitarian explanations often overlook the fact that the groups in which a person is a member determine the person's goals and aspirations. According to Appadurai, while the choices made by people often manifest themselves as specific material goods and outcomes, they are nevertheless intertwined with more general cultural norms. ${ }^{44}$ These norms, in turn, are not the sole product of rational calculations; rather, they are acquired in what Bourdieu terms as the habitus of the person. ${ }^{45}$ It is the habitus - the attitudes, norms, and practices of those residing in the person's social world - that causes seeming irrational acts to be considered reasonable.

\footnotetext{
${ }^{42}$ See Sen, "Gender and Cooperative Conflicts;" Hoodfar, Between Marriage and the Market, Bina Agarwal, "Bargaining' and Gender Relations: Within and Beyond the Household," Feminist Economics 3, no. 1 (1997): 1-51.

${ }^{43}$ Hoodfar, Between Marriage and the Market, 12.

${ }^{44}$ Appadurai, "The Capacity to Aspire."

${ }^{45}$ Pierre Bourdieu, The Logic of Practice, trans. Richard Nice (Cambridge: Polity Press, 1990).
} 


\section{Aspirations-Bounded Rationality}

Understanding how people can consider seemingly irrational acts as logical requires that we assess behaviors in terms of aspirations-bounded rationality, which posits that choices and behaviors stem from motivation. The factors that affect a person's motivations, in turn, arise from his or her ideas, hopes, and beliefs about the future. ${ }^{46}$ Seemingly irrational acts become understandable if we know enough about the person's aspirations, about the people with whom the person socializes or interacts with, and about the aspirations gap-detailed below— that the community surrounding the person gives rise to.

The notion of aspirations-bounded rationality suggests that people make choices that are neither the result of pure emotion nor pure utility maximization, but of their aspirations, desires, and motivations for the future. Youth act rationally, but within the bounds set by their culture, of which aspirations constitute a significant part. While socioeconomically disadvantaged youth may aspire to have a better material standard of living, they may also want to maintain their dignity, to be close to their families, and to be morally upright. ${ }^{47}$ These aspirations, in turn, not only serve as drivers of individual behavior, but also determine the boundaries of individual conduct. So, for example, many young people I came to know through my research in Iran refused to leave their towns in search of better opportunities elsewhere because they would no longer be near their families, a value that took precedence over any economic gains they would make if they moved. According to one young 17-year-old bazaar vendor I spoke with, a person can make money by finding employment elsewhere, but he said that there was no point since there would be no one around to share the wealth with. ${ }^{48}$

In another instance, Qasim, a struggling, low-income man in his twenties left his stable formal sector job to become a laborer in the informal economy, hauling goods for clients from one part of town to another. The formal sector job, according to Qasim, “didn't bring home the bread." ${ }^{49}$ In his new job, Qasim was able to make enough money to save face in front of his well-

\footnotetext{
${ }^{46}$ Ibid.

${ }^{47}$ Ray, "Aspirations, Poverty and Economic Change."

${ }^{48}$ Interview with author, Tehran, 2011.

${ }^{49}$ Interview with author, Tehran, 2011.
} 
off brothers and to "not come up short." ${ }^{50}$ Aspirations are therefore part of a "structure of ideas which locates them [aspirations] in a larger map of local ideas and beliefs about: life and death, the nature of worldly possessions, the significance of material assets over social relations, the relative illusion of social permanence for a society, [and] the value of peace or warfare." ${ }^{51}$

In arguing that aspirations shape action, I build on the work of Arjun Appadurai, and what he terms as the capacity to aspire. For Appadurai, there are two issues concerning this cultural capacity. First, the capacity to aspire is formed in a person's social life. However, aspirations are unevenly distributed in a population. The poor are at a disadvantage compared to their wealthier counterparts since they do not have the extent of experiences, opportunities, resources, and power necessary to link "material goods and opportunities to more general possibilities and options... and back again." ${ }^{2}$ Indeed, there is a correlation between objective realities and subjective aspirations. Youth from low income families, for example, are much less likely to realize the concrete pathways necessary to achieve a particular aspiration than are middle-class youths who have grown up in a social world surrounded by those who are able to easily navigate between their abstract desires and their concrete experiences. ${ }^{53}$

Subsequently, desires such as unwillingness to leave certain towns, or a preference for informal institutional arrangements that may ultimately lead to the perseverance of poverty cycles, originate from a less well-developed capacity to translate aspirations into concrete ends. As I argue, the result of this relative lack of a capacity to aspire is the development of more modified goals that are in line with a person's everyday lived experiences. In the following sections, I explore the issues that Appadurai raises as they relate to understanding youth as aspirations-bounded rational actors. In doing this, I focus primarily on fleshing out the determinants of aspirations and the effects of aspirations on individual behavior.

\footnotetext{
${ }^{50}$ Ibid.

${ }^{51}$ Appadurai, “The Capacity to Aspire," 68.

${ }^{52}$ Ibid., 68-69.

${ }_{53}$ Jay MacLeod, Ain't No Makin' It: Leveled Aspirations in a Low-Income Neighborhood (Boulder, CO: Westview Press, 1987).
} 


\section{Determinants of Aspirations: Group Memberships}

According to Merton's reference group theory, a person tends to compare his or her achievements, aspirations, and characteristics to reference groups of people who occupy a particular social position that the person aspires to. ${ }^{54} \mathrm{As}$ Debraj Ray points out, youth draw an "aspirations window" from the lives, achievements, or ideals of their "zone of 'similar', 'attainable' individuals" that form their "cognitive world." ${ }_{55}$ People that are close to a young person spatially, economically, or socially influence the type of information that young people receive about their lives. What are determinants of a youth's aspirations window? Peers, restrictions to communication with and observations of successful persons within one's neighborhood, and the amount of mobility or perceived mobility within one's society are some of the dimensions that may inform a young person's strategies and aspirations window. ${ }^{56}$

The idea that social as opposed to individual-level characteristics influence people's aspirations draws from Durlauf's memberships theory of poverty. ${ }^{57}$ According to Durlauf, the characteristics and behaviors of the groups in which a person is a member play an important role in the person's life outcomes. While a person makes decisions based on his or her preferences and beliefs, these preferences and beliefs are shaped by grouplevel influences such as peer effects and role models that produce "imitative behaviors." ${ }^{58}$ For example, the probability that a young person will stay in high school will be higher if his/her peers are also opting to graduate. The relative lack of extremism among poor and uneducated youth in countries like Morocco, Lebanon, Turkey, and Jordan as compared to their educated, middle-class peers can be explained in a similar frame: these youth are simply not continuously exposed to reference groups (kin, peers, neighbors) that have opted to engage in radicalism. ${ }^{59}$

\footnotetext{
${ }^{54}$ Robert K. Merton and Alice Kitt Rossi, "Contributions to the Theory of Reference Group Behavior," in Continuities in Social Research: Studies in the Scope and Method of "The American Soldier," eds. Robert K. Merton and Paul F. Lazarsfeld (New York, NY: The Free Press, 1950).

${ }^{55}$ Ray, "Aspirations, Poverty and Economic Change," 1.

${ }^{56}$ Ibid.

${ }^{57}$ Steven N. Durlauf, "Groups, Social Influences and Inequality," in Poverty Traps, eds. Samuel Bowles, Steven N. Durlauf, and Karla Hoff (Princeton and New York, NY: Princeton University Press and Russell Sage Foundation, 2006), 141-176.

${ }^{58}$ Ibid., 147.

${ }^{59}$ John L. Esposito and Dalia Mogahed, "What Makes a Muslim Radical?” Common Ground Nerws Service, November 28, 2006, www.commongroundnews.org/article.php?id=3205.
} 
Membership theory thus enables us to understand the role that cultural norms play in informing people's strategies and calculations. While these strategies may not be the most rational decisions for maximizing economic security, they are nevertheless in accord with the young person's specific worldviews and beliefs due to his/her desire to fit into the community.

But how can we account for variations in outcomes that occur within a particular subgroup-one characterized, in this case, by youthhood and socioeconomic marginalization? According to Durlauf, it is membership in these endogenous groups that exerts strong effects on people. There are various forms of endogenous group memberships that influence youths' aspirations. Some may take the form of peer groups, as described above, while others may take the form of the particular sociopolitical environment that these youth are located in. Khoury-Machool's study of cyber-resistance among Palestinian youth may be a useful example. ${ }^{60}$ Palestinian youths' appropriation of the Internet and the subsequent evolution of new media in Palestine stem from these young people's quest to resist the consequences of Israeli occupation. These aspirations, in turn, are engendered by these youths' joint membership and operation in a unique sociopolitical context marked by uprisings and violence. Residential neighborhoods in which youth grow up may serve as yet another endogenous group membership that shapes their aspirations. ${ }^{61}$

My own research among youth residing in low-income neighborhoods in the Iranian cities of Sari and Tehran suggests that many of the young men set career goals based on their preferences to live within their own communities - communities that place a high value on being close to one's family. Finally, factors that affect aspirations may come from schooling. Indeed, there is statistical evidence from Egypt indicating that young people who go to school are significantly more likely than their unschooled counterparts to have role models that they might aspire to in the future. ${ }^{62}$

\footnotetext{
${ }^{60}$ Makram Khoury-Machool, “Cyber Resistance: Palestinian Youth and Emerging Internet Culture," in Being Young and Muslim: New Cultural Politics in the Global South and North, eds. Linda Herrera and Asef Bayat (Oxford: Oxford University Press, 2010).

${ }^{61}$ Durlauf, "Groups, Social Influences and Inequality."

${ }^{62}$ Sahar E1 Tawila, Barbara Ibrahim, and Hind Wassef, "Social Change and Parent-Adolescent Dynamics in Egypt," in “The New Arab Family," ed. Nicholas Hopkins, special issue, Cairo Papers in Social Science 24, no. 1-2 (Spring/Summer, 2001).
} 
Aspirations-bounded rationality, then, allows us to understand how individual desires and choices for what is meaningful to pursue are often defined by experience with, and observation of, the endogenous groups to which the person belongs. They do not exist in social isolation as personal preferences and interests, which is the standard assumption in household bargaining models. Even though these accounts depart from conventional economic approaches by examining the role that cultural contexts, such as the household, play in the strategies that people deploy, these perspectives nevertheless fail to observe how aspirations themselves constitute a significant element of culture. Similarly, the idea of socially determined aspirations also departs from perceptions of the affective impulsiveness of youth. Indeed, the underlying assumption in these emotional action accounts is the "spontaneous discharge of internal influences rather than motivated conduct." ${ }^{63}$ However, as we have seen, endogenous group memberships shape what youth think is worth pursuing, which then becomes a guide for calculated strategy and action.

\section{Effects of Aspirations on Behavior}

To understand how these aspirations, once developed, influence youth behaviors, I turn again to Ray and his concept of an aspirations gap. In what follows, I flesh out this concept as it relates to the behavior of poor youth in the Middle East by drawing from my own ethnographic fieldwork in Iran. In so doing, I further highlight some of the conceptual haze surrounding the idea.

The aspirations gap is defined as the "difference between the standard of living that's aspired to and the standard of living that one already has." ${ }_{64}$ What is important about this gap for the purposes of this discussion is Ray's proposition that youth invest minimal effort both when this aspirations gap is too high and when it is too low. Young people who aspire to a standard of living that is close to their current living situation will exert little effort to raise their aspirations. Similarly, youth who aspire to a life that is very far from their current life situation will also have little incentive to raise these

\footnotetext{
${ }^{63}$ Portes, "Rationality in the Slum," 271.

${ }^{64}$ Ray, "Aspirations, Poverty and Economic Change," 3.
} 
standards, because of the belief that it would be too difficult to achieve their aspirations and therefore not worth the effort. According to Ray, the concept of an aspirations gap attunes us to the fact that in order for youth to improve themselves, the people who surround them must fare better than the youth do, but not so much better that the young person's aspirations become frustrated.

We can use Ray's concept of the aspirations gap to understand the behaviors of groups of poor youth in low-income communities in the Middle East. Take, for example, the experiences of some young men I came to know in the cities of Sari and Tehran. The individuals that surrounded these young men on a daily basis-uncles, friends, colleagues, and cousins-were largely engaged in some form of productive employment. Whether comprised of carpentry, blacksmithing, trucking, or vending goods, these jobs enabled these individuals to gain elements of upward mobility. As one of the young men, 15-year-old Nasser, stated, "I'm going to buy an 18 -wheeler...I know a guy who bought one [to transport goods] and now he's rich!" 65 As Nasser's comments illustrate, these young men aspired to the career choices of those individuals who experienced similar economic situations as themselves, but who have since managed to move out of poverty. Often, these individuals with similar experiences were entrepreneurs in the informal economy who ran their own small businesses. Take the comments of 17-year-old Mohammad who worked in Tehran's metro station selling random small goods:

I met this guy in the metro station who sells toothbrushes and tissues and these sorts of things and he said that vending makes good money. I decided to try it out. So my wife and I bought all this stuff for 20,00030,000 tomans...we work in shifts selling them. ${ }^{66}$

\footnotetext{
${ }^{65}$ Interview with author, Tehran, 2011.

${ }^{66}$ Interview with author, Tehran, 2011. At the time of fieldwork, 30,000 tomans amounted to approximately 20-30 USD. Mohammad made these comments as I spoke with him near the metro station. Following sociological convention, I use no quotation marks when I was unable to capture exact sentences, but only the kernel of what was said. See Jeffrey L. Kidder, "Parkour: Adventure, Risk and Safety in the Urban Environment," Qualitative Sociology 36, no. 3 (2013): 231-250.
} 
Youth like Mohammad and Nasser drew their aspirations from the mobility experiences of others like them. Looking to the experiences of those who were able to overcome their initial disadvantage provided these young men with examples of aspiration. While these youth wanted to be members of the middle and upper classes, the gap between where they wanted to be and where they were in reality was simply too huge for them to cross by simply emulating the experiences of the middle class. They knew that to attain socioeconomic mobility, they had to take incremental steps up the proverbial ladder, and the lives of the working class provided them with the blueprint for doing so. ${ }^{67}$ The comments of Amin, a 17-year-old farm laborer, are representative:

"Rich kids? They don't have a care in the world. I knew a few rich kids in my school who were really up there. Every recess, they would eat four sandwiches at a time! And they always had new clothes on. My personal role model is this electrician I worked for when I was in $6^{\text {th }}$ grade. He worked really, really hard and now he has a car, several two-story houses and he's really up there!"68

The problem that arises here, according to Ray, is if people like Amin and Nasser exert much effort in emulating the experiences of these workingclass role models, but then ultimately experience no real change in their life conditions. Will youth like Mohammad, Amin, or Nasser ultimately embrace alternative, oppositional-leaning aspirations to attain relief if they are unable to improve their living conditions? As Ray emphasizes, people can be pushed into alternative "aspirational dimensions (religion)" which emanate from failure to achieve "another aspirational dimension (economic wellbeing)." ${ }^{99}$ Similar to Davies' rising expectations theory, Ray's

\footnotetext{
${ }^{67}$ Martín Sánchez-Jankowski found a similar pattern in his study of African-American poverty in the US in "The Concentration of African-American Poverty and the Dispersal of the Working Class: An Ethnographic Study of Three Inner-City Areas," International Journal of Urban and Regional Research 23, no. 4 (1999): 619-637.

${ }^{68}$ Interview with author, Sari, 2011.

${ }_{69}$ Ray, "Aspirations, Poverty and Economic Change," 7; See also Sánchez-Jankowski, "The Concentration of African-American Poverty and the Dispersal of the Working Class."
} 
theory suggests that when aspirations are ultimately abruptly frustrated, a revolutionary situation - in this case, religious extremism-can occur. ${ }^{70}$ Thus, according to Ray's proposition, if the young men portrayed in my research failed to achieve a tangible sense of economic relief, then this will cause them to become militant, in an attempt to regain the dignity and power that they feel is lacking in their day-to-day lives.

However, the relative absence of extremist behavior among poor youth in Iran casts this assertion into doubt. This suggests that rather than a necessary aspirations displacement, these youth develop more modified goals over time that are in line with their realities. They create strategies, such as engaging in alternative forms of work in the informal economy, or participating in networks of reciprocal exchange, to meet their newly modified aims. When faced with economic uncertainty, many of the youth that I interviewed switched jobs or their line of work to hauling merchandise or selling handmade goods. Others relied on horizontal networks of exchange with friends and family to borrow goods such as computers that they could otherwise not afford to buy.

While not all of these alternative strategies embraced by youth were the most efficient pathways to attaining larger leaps of socioeconomic mobility - transitions that necessarily require the connections, knowledge, and experience that their middle or upper-class counterparts may havethese activities nevertheless functioned to keep these youth satisfied by meeting their newly modified and lowered expectations. As Davies points out, it is highly unlikely that a revolutionary situation will occur when there is the "continued, unimpeded opportunity to satisfy new needs, new hopes, new expectations."71

As Bayat has stated, Middle Eastern states often encourage these types of self-help efforts in an effort to transfer some of the social welfare onus to citizens. ${ }^{72}$ Simultaneously, many Middle Eastern states often clamp down

\footnotetext{
${ }^{70}$ James C. Davies, “Toward a Theory of Revolution," American Sociological Review 27, no. 1 (1962): 5-19.

${ }^{71}$ Ibid., 17.

72 Asef Bayat, "Globalization and the Politics of the Informals in the Global South," in Urban Informality: Transnational Perspectives from the Middle East, Latin America and South Asia, eds. Ananya Roy and Nezar AlSayyad (Lanham, MD: Lexington Books, 2004).
} 
on collective radical acts. As such, many economically marginalized youth in the region, rather than engage in radicalism in response to a perceived lack of change in their lives, engage in more individualistic strategies to fulfill their new aspirations and needs and to improve their lives. This is not to argue that illegal behavior in the criminal economy-theft, prostitution, robbery, and participation in the drug trade-is not an alternative pathway. Rather, it is to provide insight into why the presence of economic hardship does not necessarily and always manifest itself in radical political form. Illegal and informal activities are explored among some groups of poor youth in the Middle East, like many of their counterparts in the developing and developed world, as a mechanism to gain incremental advancements and to meet personal and familial needs.

Indeed, the poor youth I interviewed who engaged in alternative informal arrangements to meet their needs subsequently communicated this information to peers. Thus, when assessing alternative options, youth who had experienced an aspirations failure mimicked the strategies of those within their local communities. These self-supporting and informal institutional arrangements were attractive and desirable because they enabled these youth to meet their needs, to attain a sense of purpose, and to incrementally improve their lives. Paradoxically, the fact that strategies like street vending and hauling merchandise enabled disadvantaged youth to meet their newly modified aspirations facilitated the reproduction of poverty cycles, since it left a declining need among these youth to develop their human capital, for instance, which could ultimately provide them with greater security and social protection.

\section{Conclusion}

One of the major consequences of rising youth unemployment in the Middle East has been the tendency to view the region's youth as either a frustrated mass that is ripe for radicalism or as strict rational choice agents that act according to their individual and material maximizing preferences and interests. As I have argued, both assumptions suffer from major shortcomings. These are reflected in these theories' inability to account for the relative absence of political radicalism among the young and poor in many countries in the Middle East, and for the presence of group-level influences that shape the various economic and non-economic goals that people find worthy of pursuing. 
I have suggested that aspirations-bounded rationality may provide an alternative lens with which to view and to understand the behaviors of socioeconomically disadvantaged youth in the region. In this perspective, the behaviors of poor youth are not determined solely by economic interests or by pure emotion, but by their aspirations, which, in turn, are influenced by social factors. These youth struggle and devise calculated strategies within the household, school, workplace, neighborhood, and community to pursue aspirations that are conditioned by the values, beliefs, and strategies of action of other people in their endogenous groups.

As Appadurai has noted, these aspirations are often expressed in terms of particular material goods such as clothes, cars, and pricey electronic goods. As such, rational choice theorists "lose sight of the higher order normative contexts within which these wants are gestated and brought into view," 73 such as desires to fit in, to be close to one's family, or to prevent the loss of one's dignity.

At the same time, as Ray has incisively argued, when these aspirations are either too much or too little, people will not feel an urgent need to improve their conditions. This failure to exert effort may manifest itself in frustration in the former case or fatalism in the latter. Scholars who implicitly impute irrationality to young people in the Middle East often stop their analyses here and argue that such feelings of fatalism and frustration may lead youth to embrace other aspirations, most often radicalism. This assertion, however, betrays the experiences of many youth in the Middle East who often turn to alternative informal institutional arrangements to meet their needs and to provide them with a sense of purpose. Yet, as Bayat reminds us, the question remains regarding how far these youth will actually be able to go simply by persisting.

The perspective of aspirations-bounded rationality can allow us to see how poor youth in the Middle East, given broader structural constraints, are able to attain incremental advancements within poverty. These accumulative gains may serve as intermediate mechanisms leading to larger leaps of socioeconomic mobility over time. However, it must be noted that the very mechanisms that enable these youth to gain elements of mobility can also serve to sustain them within poverty traps. By holding together these youths'

${ }^{73}$ Appadurai, “The Capacity to Aspire,” 68. 
lives and making them functional, these processes can also constrain the need for higher education and better connections-social goods that could prove essential for engendering more lasting changes in a young person's life. Any hope of dealing with youth poverty in the Middle East thus requires insight into how socially-determined aspirations work at the ground level to both provide a sense of purpose for the actors and ultimately, perhaps, to reproduce cycles of inequality. 


\section{BIBLIOGRAPHY}

Agarwal, Bina. "Bargaining' and Gender Relations: Within and Beyond the Household." Feminist Economics 3, no. 1 (1997): 1-51.

Appadurai, Arjun. "The Capacity to Aspire: Culture and the Terms of Recognition." In Culture and Public Action, edited by Vijayendra Rao and Michael Walton, 59-84. Stanford, CA: Stanford University Press, 2004.

Barber, Lionel. "Restive Young a Matter of National Security." Financial Times, June 2, 2008, www.ft.com/reports/youth2008.

Bayat, Asef. "Globalization and the Politics of the Informals in the Global South." In Urban Informality: Transnational Perspectives from the Middle East, Latin America and South Asia, edited by Ananya Roy and Nezar AlSayyad, 79-105. Lanham, MD: Lexington Books, 2004.

- Making Islam Democratic: Social Movements and the Post-Islamist Turn. Stanford, CA: Stanford University Press, 2007.

- Street Politics: Poor People's Movements in Iran. New York, NY: Columbia University Press, 1997.

Bayat, Asef, and Eric Dennis. "Who is Afraid of Ashwaiyyat? Urban Change and Politics in Egypt." Environment \& Urbanization 12, no. 2 (2000): 185-199.

Bédoui, Mongi, and Gouia Ridha. "Les Politiques de Lutte Contre L'Exclusion Sociale en Tunisie" (Policies for Fighting Social Exclusion in Tunisia). Working Paper 88, International Institute of Labor Studies, International Labor Office, 1996.

Boudarbat, Brahim, and Aziz Ajbilou. "Youth Exclusion in Morocco: Context, Consequences, and Policies." The Middle East Youth Initiative Working Paper no. 5. Washington, DC, and Dubai: Wolfensohn Center for Development at Brookings and the Dubai School of Government, September 2007.

Bourdieu, Pierre. The Logic of Practice. Translated by Richard Nice. Cambridge: Polity Press, 1990. 
Davies, James C. “Toward a Theory of Revolution.” American Sociological Review 27, no. 1 (1962): 5-19.

Durlauf, Steven N. "Groups, Social Influences and Inequality." In Poverty Traps, edited by Samuel Bowles, Steven N. Durlauf, and Karla Hoff, 141-176. Princeton and New York, NY: Princeton University Press and Russell Sage Foundation, 2006.

E1 Tawila, Sahar, Barbara Ibrahim, and Hind Wassef. "Social Change and Parent-Adolescent Dynamics in Egypt.” In "The New Arab Family," ed. Nicholas Hopkins. Special issue. Cairo Papers in Social Science 24, no. 1-2 (Spring/Summer, 2001): 214-247.

Esposito, John L., and Dalia Mogahed. "What Makes a Muslim Radical?" Common Ground News Service, November 28, 2006. www. commongroundnews.org/article.php?id=3205.

- Who Speaks for Islam? What a Billion Muslims Really Think. New York, NY: Gallup Press, 2007.

Hafez, Mohammed M. "Rationality, Culture, and Structure in the Making of Suicide Bombers: A Preliminary Theoretical Synthesis and Illustrative Case Study." Studies in Conflict E Terrorism 29, no. 2 (May 2006): 165-185.

Hashemi, Manata. "Waithood and Face: Morality and Mobility among LowerClass Youth in Iran.” Qualitative Sociology 38, no. 3 (2015): 261-283.

Herrera, Linda, and Asef Bayat. Being Young and Muslim: New Cultural Politics in the Global South and North. Oxford: Oxford University Press, 2010.

Hoodfar, Homa. Between Marriage and the Market: Intimate Politics and Survival in Cairo. Berkeley, CA: University of California Press, 1997.

Inhelder, Bärbel, Harold H. Chipman, and Charles Zwingmann, eds. Piaget and His School: A Reader in Developmental Psychology. New York, NY: Sprinter-Verlag, 1976.

Ismail, Salwa. Political Life in Cairo's New Quarters: Encountering the Everyday State. Minneapolis, MN: University of Minnesota Press, 2006.

James,Allison, and Alan Prout. "A New Paradigm for the Sociology of Childhood? Provenance, Promise and Problems." In Constructing and Reconstructing Childhood: Contemporary Issues in the Sociological Study of Childhood, edited by Alan Prout and Allison James, 7-32. London: The Falmer Press, 1997. 
Khashan, Hilal. "Collective Palestinian Frustration and Suicide Bombings." Third World Quarterly 24, no. 6 (2003): 1049-1067.

Khoury-Machool, Makram. "Cyber Resistance: Palestinian Youth and Emerging Internet Culture."In Being Young and Muslim: New Cultural Politics in the Global South and North, edited by Linda Herrera and Asef Bayat, 113-127. Oxford: Oxford University Press, 2010.

Kidder, Jeffrey L. "Parkour: Adventure, Risk and Safety in the Urban Environment." Qualitative Sociology 36, no. 3 (2013): 231-250.

Kouaouci, Ali. "Population Transitions, Youth Unemployment, Postponement of Marriage and Violence in Algeria." The Journal of North African Studies 9, no. 2 (2004): 28-45.

Krueger, Alan B. What Makes a Terrorist? Economics and the Roots of Terrorism. Princeton, NJ: Princeton University Press, 2007.

Laitin, David D. Hegemony and Cultures: Politics and Religious Change among the Yoruba. Chicago, IL: University of Chicago Press, 1986.

Lipset, Seymour Martin. Political Man: The Social Bases of Politics. Garden City, New York: Anchor Books, 1963.

MacLeod, Arlene Elowe. Accommodating Protest: Working Women, the New Veiling, and Change in Cairo. New York, NY: Columbia University Press, 1991.

MacLeod, Jay. Ain't No Makin' It: Leveled Aspirations in a Low-Income Neighborhood. Boulder, CO: Westview Press, 1987.

Merton, Robert K., and Alice Kitt Rossi. "Contributions to the Theory of Reference Group Behavior.” In Continuities in Social Research: Studies in the Scope and Method of "The American Soldier," edited by Robert K. Merton and Paul F. Lazarsfeld, 40-105. New York, NY: The Free Press, 1950.

Moaddel, Mansoor, and Stuart A. Karabenick. "Religious Fundamentalism among Young Muslims in Egypt and Saudi Arabia." Social Forces 86, no. 4 (2008): 1675-1710.

Muñoz, Gema Martín. "Arab Youth Today: The Generation Gap, Identity Crisis and Democratic Deficit." In Alienation or Integration of Arab Youth: Between Family, State and Street, edited by Roel Meijer, 17-27. Richmond, Surrey: Curzon Press, 2000. 
Portes, Alejandro. "Rationality in the Slum: An Essay on Interpretive Sociology." Comparative Studies in Society and History 14, no. 3 (June 1972): 268-286.

Rahnema, Saeed. "Radical Islamism and Failed Developmentalism." Third World Quarterly 29, no. 3 (2008): 483-496.

Ray, Debraj. "Aspirations, Poverty and Economic Change." Working Paper, New York University and Instituto de Análisis Económico (CSIC), 2003. http://www.econ.nyu.edu/user/debraj/Papers/povasp01.pdf.

Richards, Alan, and John Waterbury. A Political Economy of the Middle East. Boulder, CO: Westview Press, 2008.

Salehi-Isfahani, Djavad. “Growing up in Iran:Tough Times for the Revolution's Children.” Brown Journal of World Affairs 15, no. 1 (2008): 63-74.

Salehi-Isfahani, Djavad, and Daniel Egel. "Youth Exclusion in Iran: The State of Education, Employment and Family Formation." The Middle East Youth Initiative Working Paper no. 3. Washington, DC, and Dubai: Wolfensohn Center for Development at Brookings and the Dubai School of Government, September 2007.

Sánchez-Jankowski, Martín. Cracks in the Pavement: Social Change and Resilience in Poor Neighborhoods. Berkeley, CA: University of California Press, 2008.

—. "The Concentration of African-American Poverty and the Dispersal of the Working Class: An Ethnographic Study of Three Inner-City Areas." International Journal of Urban and Regional Research 23, no. 4 (1999): 619-637.

Scott, James. Weapons of the Weak: Everyday Forms of Peasant Resistance. New Haven, CT: Yale University Press, 1985.

Sen, Amartya. "Gender and Cooperative Conflicts." In Persistent Inequalities: Women and World Development, edited by Irene Tinker, 123-150. Oxford: Oxford University Press, 1990.

Silver, Hilary. "Social Exclusion: Comparative Analysis of Europe and Middle East Youth." The Middle East Youth Initiative Working Paper no. 1 Washington, DC, and Dubai: Wolfensohn Center for Development at Brookings and the Dubai School of Government, September 2007. 
Simon, Herbert. Models of Man: Social and Rational-Mathematical Essays on Rational Human Behavior in a Social Setting. Hoboken, NJ: Wiley, 1957. Singerman, Diane. Avenues of Participation: Family, Politics and Networks in the Urban Quarters of Cairo. Princeton, NJ: Princeton University Press, 1995.

Swidler, Ann. Talk of Love: How Culture Matters. Chicago, IL: University of Chicago Press, 2001.

Williams, Raymond. Marxism and Literature. Oxford: Oxford University Press, 1977.

World Bank. World Development Report 2007: Development and the Next Generation. Washington DC: World Bank, 2006. 


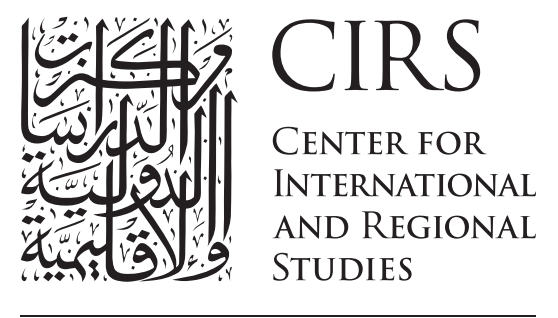

GEORGETOWN UNIVERSITY SCHOOL OF FOREIGN SERVICE IN QATAR 


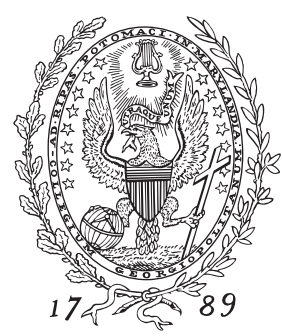

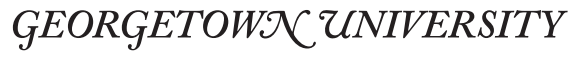

School of Foreign Service in Qatar

Center for International and Regional Studies

$$
\begin{gathered}
\text { P.O. Box } 23689 \\
\text { Doha, Qatar }
\end{gathered}
$$

http://cirs.georgetown.edu

Tel +974 44578400

Fax +974 44578401 


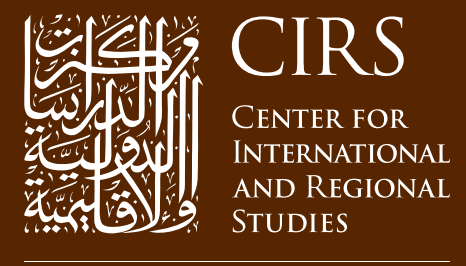

GEORGETOWN UNIVERSITY SCHOOL OF FOREIGN SERVICE IN QATAR 